\title{
Magnetorheological Fluid Devices: an Advanced Solution for Active Control of the Wood Manufacturing Process
}

C. Fragassa
Assistant Professor
University of Bologna
Italy
Department of Industrial Engineering
L. Berardi
Engineer
Autec Italia Automation Technology
Italy
G. Balsamini
Engineer
Autec Italia Automation Technology
Italy

\section{INTRODUCTION}

Within the field of magneto-fluid dynamics or magnetohydrodynamics (MHD), which involves the study of electrically conductive fluid flow in the presence of magnetic fields, rheology is becoming of growing importance thanks to a number of new practical applications. This field of study covers the flow and plastic deformation of soft matter under the action of external forces, including magnetic and electric fields. The physical characteristics, including viscosity and plasticity, of rheological materials are strongly dependent on their microscopic and macroscopic structures, as well as the presence of intermolecular forces. The complex physical and chemical phenomena hidden within these interactions, investigated as early as 1922 [1], are not covered by either traditional electromagnetics or fluid dynamics and are therefore of great interest to presentday research. Specifically, recent advances have typically focused on magneto-rheological (MR) and electrorheological (ER) fluids that, when subject to a magnetic or electric field, exhibit rapid variations in viscosity [2]. This unusual property has been recognized as potentially useful for a number of applications where damping of relative motion can be controlled as a function of an electrical signal present in a winding immersed in the

Received: May 2016, Accepted: June 2016

Correspondence to: Prof. Cristiano Fragassa

Department of Industrial Engineering - DIN

Alma Mater Studiorum, University of Bologna

E-mail: cristiano.fragassa@unibo.it

doi:10.5937/fmet1604333F

(C) Faculty of Mechanical Engineering, Belgrade. All rights reserved fluid. Such applications include, amongst others, devices such as dampers, joints, clutches and brakes [3, 4]. In terms of practical applications, devices exploiting electrorheological fluids have until recently monopolized the market due to their relatively simple implementation; however, magneto-rheological devices are currently seeing a more rapid uptake due to their improved performance and competitiveness [5]. As a result, devices based on the latter are currently seeing greater diffusion.

Magneto-rheological fluids consist of water or oil (mineral, synthetic or silicon-based) with 3-10 $\mu \mathrm{m}$ large iron particles in suspension at $10-40 \%$ vol. Being ferromagnetic, flow behaviour in the absence of a magnetic field is similar to that of a Newtonian fluid. With the application of an external magnetic field, however, they develop an internal viscous resistance that depends on the field strength due to polarization of the suspended particles, with non-Newtonian behaviour resulting. More specifically, the external magnetic field induces a magnetic moment, with magnetic interaction between particle dipoles leading to a non-equilibrium energy state. The particles therefore tend to move and reorder themselves to bring the system to a new minimum energy state. An energetically favourable arrangement consists of the particles aligning to form chains that are parallel to the magnetic flux. With an increase in flux, these chains become denser such that columns of connected particles are formed. Such columns, reducing the mobility of the fluid, are responsible for a macroscopic increase in viscosity [6].

Though the viscosity of a magneto-rheological fluid can be made to vary with precision under the action of 
an external magnetic field, it is the fact that this action is reversible and fast that makes these materials of particular interest for industrial applications. The time interval in which large changes in viscosity can take place is, in fact, in the order of a few milliseconds. The behaviour of the fluid itself, however, is not the only source of response delay in devices that exploit magneto-rheological fluids; indeed, delays are also associated with other characteristics, in particular the ability to create a sufficiently strong magnetic field [7, 8] [16, 17]. By overcoming these technical limits, magneto-rheological devices could potentially be applied to many different interesting roles over a broad range of sectors. Their use has been tested in several fields, including automotive and aerospace applications.

In the present article, the possibility of installing a magneto-rheological device in a woodworking machine tool as a way of controlling the speed and force of the electric spindle via a feedback loop is investigated for the first time. According to the specific function it is installed for, this device could act as a brake or a clutch inside the machine tool. This technical solution aims at improving the quality of wood machining thanks to precise tool control, shorter response times and energy savings. To be fully effective, these solutions must permit online feedback fine-tuning of process parameters [13, 14]. The study is presented in the context of a rapidly changing manufacturing environment in which performance and efficiency are of foremost importance. Machine tools have historically been purely mechanical and relatively simple; however, this is no longer sufficient for advanced applications. Customer demands for greater performance and customization have now forced manufacturers to consider a wide variety of solutions to fulfill more complex requirements. The need for intricate, multifunctional and safe $[9,10]$ machines has placed further pressure on manufacturers to improve overall productivity and flexibility. As a consequence, it is necessary to modify traditional design procedures and more effectively define and manage complexity and interrelated requirements earlier in the conceptual design phase [11, 12]. Amongst the many technical solutions, those related to the use of very uncommon materials such as magneto-rheological fluids present opportunities to achieve vast improvements in quality and precision in wood machining. The scope of the present study is therefore to identify the static and dynamic behaviour of a magneto-rheological clutch through experimental observation in the context of the application at hand.

\section{EXPERIMENTAL SET UP}

\subsection{Magneto-rheological clutch}

A LORD TFD RD-8060-1 magneto-rheological clutch, displayed in Fig. 1, was utilized for the experiments. The manufacturers state that the device is able to effect a resisting moment over the range $0-5 \mathrm{Nm}$ as a function of a DC electrical current running through windings within the device [15]. Due to the magneto-rheological nature of the fluid within the clutch, the current creates an alignment in the orientation of a large number of ferromagnetic particles that, in turn, impose precise changes in the viscosity of the fluid. This effect translates into a torque moment that opposes the rotational velocity of the device shaft, with greater current leading to a greater resistive moment. In this way, accurate torque control is achieved via an electrical signal.

The TFD RD-8060-1 is intended by the manufacturer as a low-cost solution for providing efficient and safe steering feedback to drivers of large vehicles that employ steer-by-wire ( $\mathrm{SbW}$ ) solutions. The device is capable of providing torsional resistance that is proportional to the angle of rotation, thus providing feedback to the driver and ensuring maximum sensitivity and control of the vehicle. Currently, this model is utilized in agricultural vehicles and high-value watercraft, relatively 'classical' applications in the transport industry. Potential exists, however, to apply this type of magneto-rheological clutch over a much wider range of applications in different industries. Their utilization in precision machinery and small machine tools is one such possibility, where smaller, scaleddown versions in terms of dimensions, power and cost could potentially offer performance improvements over existing technology. Their size makes them particularly apt for electronically controlled devices for rehabilitation and physical therapy, a field of current research where magneto-fluids are become of interest.

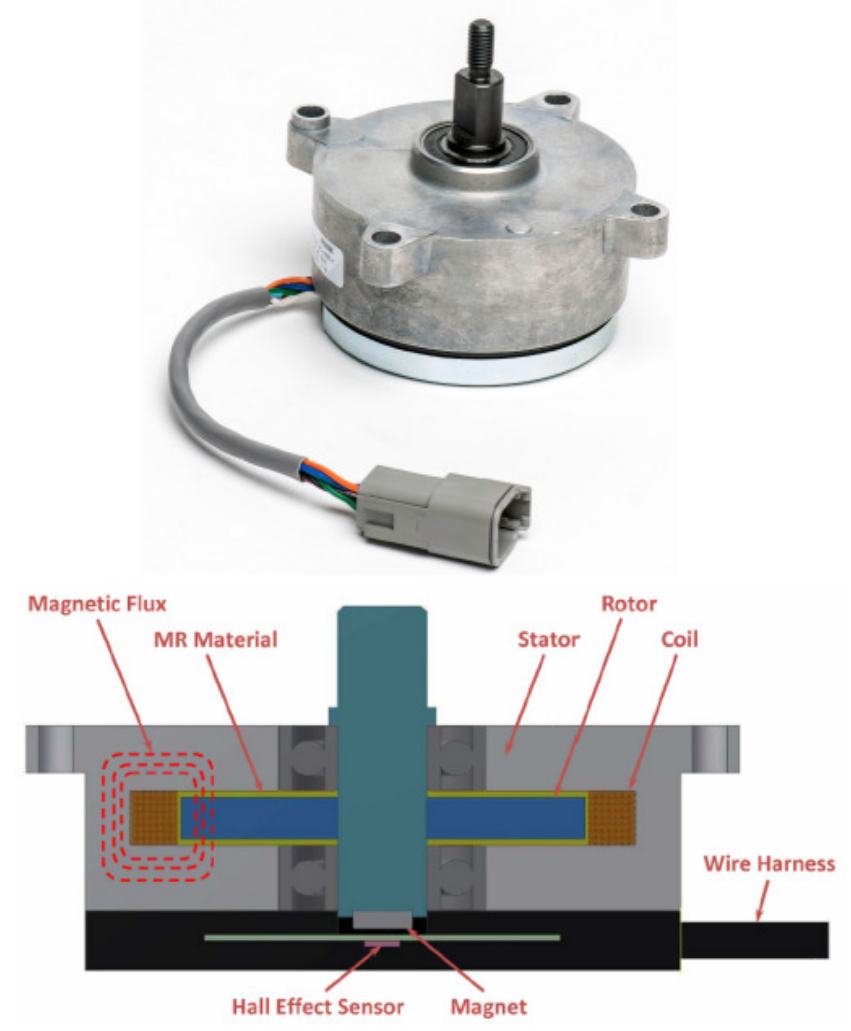

Figure 1: LORD TFD RD-8060-1 magneto-rheological clutch

\subsection{Measurement Apparatus}

Characterization of the magneto-rheological clutch required application of an external torque and measurement of the control signal current and resisting 
torsional moment. It was therefore necessary to firstly apply a torsional moment to the clutch shaft with high precision and repeatability. This was achieved by fixing two one meter long aluminum bars to the shaft at $180^{\circ}$ to one another, thus maintaining equilibrium of the unloaded system (Figs. 2A and 2B). A $5 \mathrm{~N}$ weight was then attached to one of the bars at a given distance from the axis of rotation, creating an external torsional moment at the clutch axis. The applied torque was varied by changing the distance of the weight from the axis of rotation. A torque transducer was then attached to the clutch shaft in order to measure the transmitted torque (Fig. 3C). The transducer was an AEP BRT MP80S/2 with a maximum power of $400 \mathrm{~W}$, maximum measured torque of $100 \mathrm{Nm}$ and linearity of $<0.2 \%$.
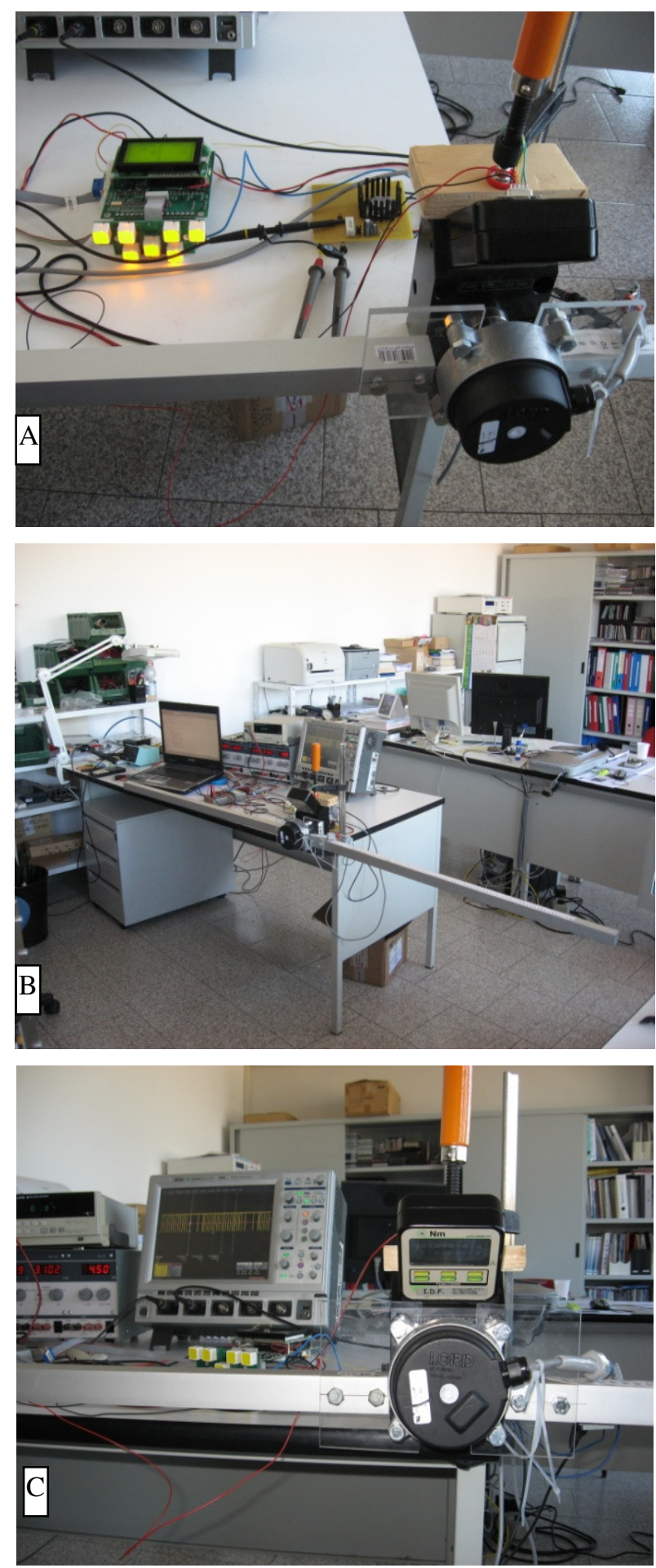

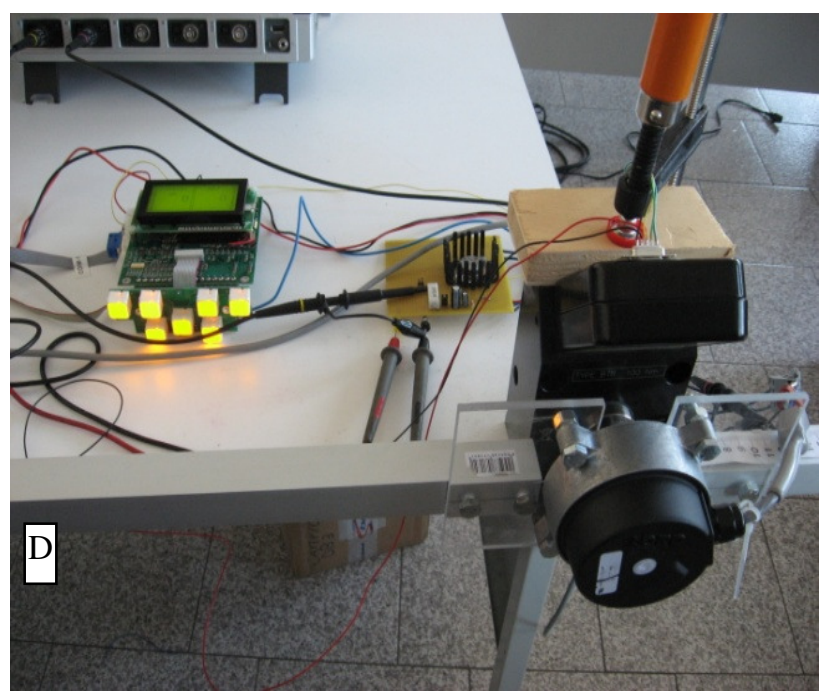

Figure 2: Experimental setup, including:

a) Magneto-rheological clutch;

b) aluminum arms;

c) torque measurement system;

d) microprocessor control board

It was then necessary to construct an electrical apparatus capable of generating the control current with an absolute angle sensor. This sensor was based on the Hall effect, providing two PWM outputs with $90^{\circ}$ phase difference to allow precise closed-loop control of the resisting torsional moment. Several preliminary tests were performed to assess the maximum rate of torque change achievable over both small and large intervals.

A microprocessor control board with analog and digital interfaces was utilized to provide DC control signals and monitoring outputs during the experiments (Fig. 2D). The analog input was necessary for feedback control based on the shunt resistance current. The processor then adjusted the duty cycle of the digital output to maintain the required constant current level. The digital input was instead necessary for reading the angle signal provided by the Hall sensor. The gain of the control system was increased over 256 steps to obtain the optimum value.

Other instruments utilized during the tests included a LeCroy Wavesurfer Xs 4 channel, $400 \mathrm{MHz} 2,5 \mathrm{GS} / \mathrm{s}$ oscilloscope, a Fluke 45 Dual Display Multimeter, a Thurlby-Thandar LCR400 precision LCR bridge and a Thurlby-Thandar PL330QMT power supply.

\section{RESULTS AND DISCUSSION}

\subsection{Static measurements}

Static tests were performed by positioning the $5 \mathrm{~N}$ weight on the aluminum arm and measuring the current necessary to maintain system equilibrium and support the load in the given position. The weight was moved progressively closer to the rotational axis, with the current measured for each position.

The Hall sensor was utilized to ensure that equilibrium was achieved in all cases by measuring the angle of shaft rotation and providing a corrective feedback signal. Figure 3 displays the nominal and experimentally measured current-torque curves. 
a)

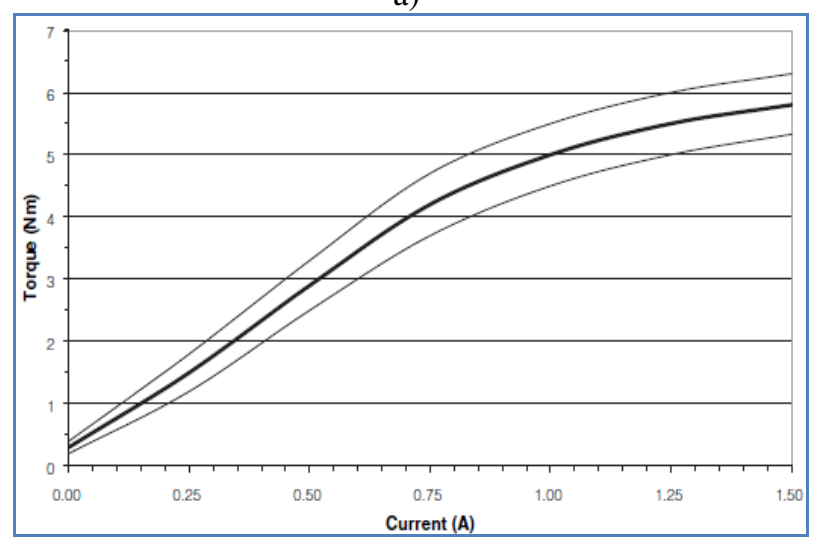

b)

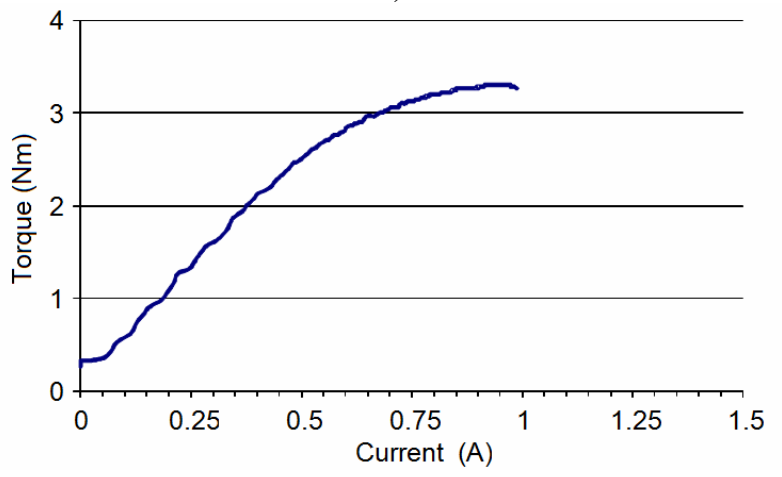

Figure 3. Current-torque curves for: a) nominal and $b$ ) experimental cases.

\subsection{Hysteresis measurements}

Subsequent measurements were performed to determine the system response to changes in load conditions. As is evident from the manufacturer load curve (Fig. 4A), the resistive torque does not follow the same curve under loading and unloading conditions, with a difference of approximately $0.5 \mathrm{Nm}$ for most of the course. The experimental load curves were obtained by gradually increasing the current to the device then subsequently reducing it once again. For each current level, the corresponding generated resistive torque was measured. This process was performed at very low shaft rotational velocity in order to obtain quasi-static conditions. The resulting curves, displayed in Fig. 4B, show evidence of hysteresis corresponding to the area between the limiting curves, with similar values to those provided by the manufacturer.

a)

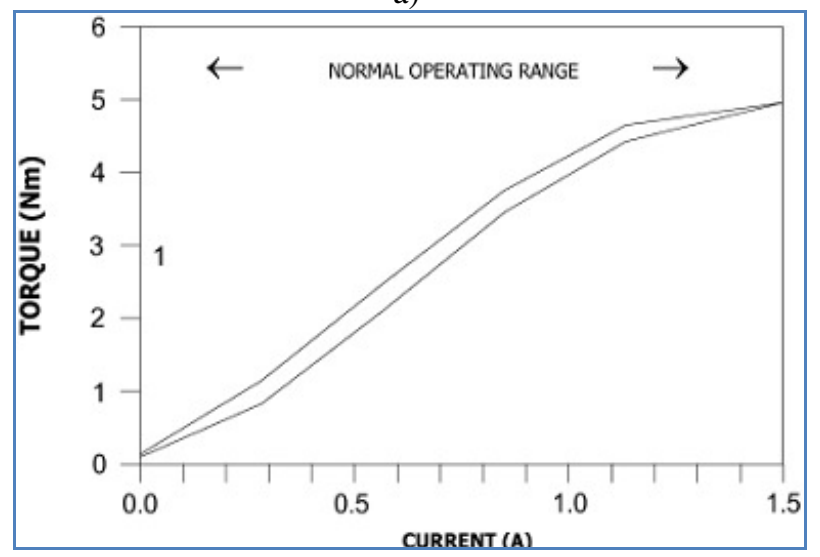

b)

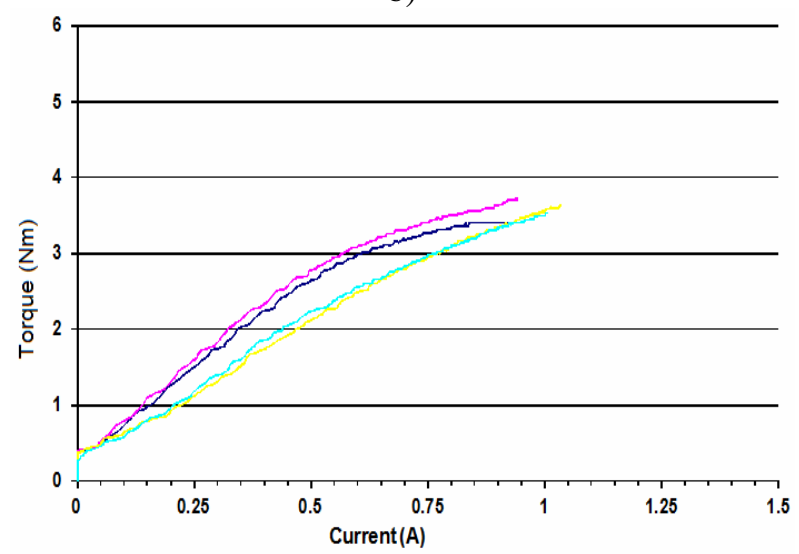

Fig. 4: Loading and unloading hysteresis current-torque curves for: a) nominal and b) experimental cases.

\subsection{Dynamic measurements}

Considering the principle applications for which use of the magneto-rheologic clutch is foreseen, it was necessary to determine the resistive torque under dynamic conditions. A test rig was therefore developed to provide continuous rotating motion to the device shaft. Figures 5-7 display the main components, including a DC motor with reduction gearbox and a mounting structure that was connected to the torque measurement system.

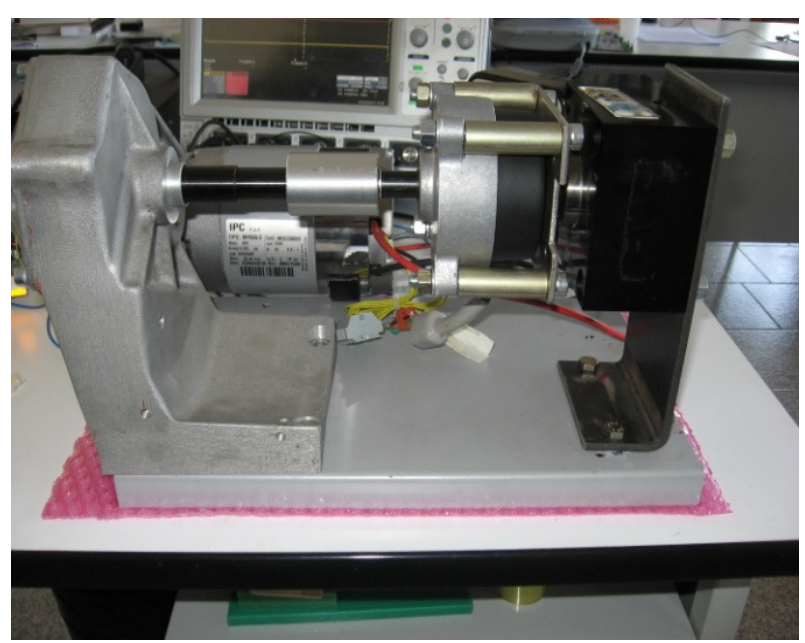

Fig. 5: DC motor with reduction gearbox.

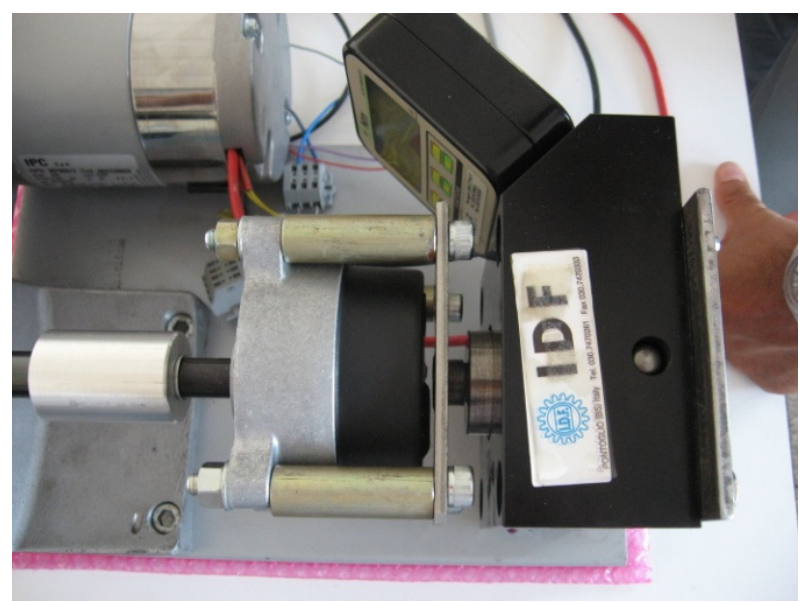

Fig. 6: Mounting structure with torque measurement. 




Fig. 7: Execution of experiments.

While manual data acquisition from the BRT instrument display was possible for the previous static and quasi-static tests, it was necessary to interface this device with a computer acquisition system for the dynamic tests, recording both the torque and current signals as functions of time. The dynamic hysteresis cycle was determined in this way with current levels of $0.25 \mathrm{~A}, 0.50 \mathrm{~A}, 0.75 \mathrm{~A}$ and $1 \mathrm{~A}$. Figure 8 displays the torque (upper curve) and current (lower curve) as functions of time under dynamic conditions with the rotational velocity of the device held constant.

The same data is displayed in Fig. 9 in the form of torque versus current. It is evident that the hysteresis cycle is of higher amplitude than under static conditions. The torque trajectory follows a rounded trend in correspondence with a reduction and subsequent increase in current. These results highlight the necessity for closed loop control in order to ensure that the torque follows the required profile.

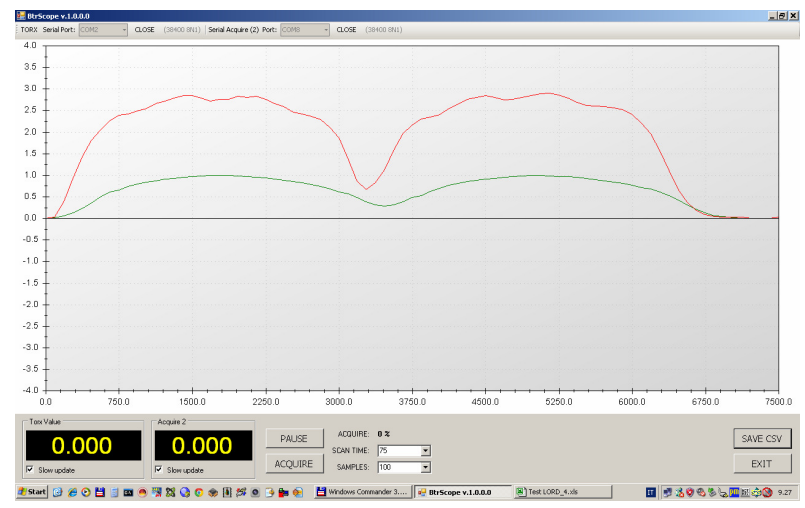

Fig. 8: Torque (upper curve) and current (lower curve) as functions of time under dynamic conditions.

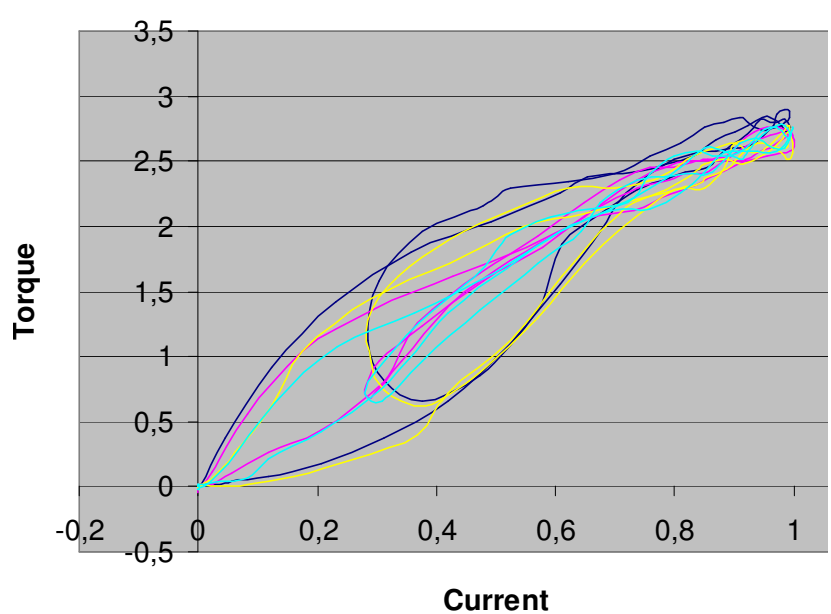

Fig. 9: Current-torque hysteresis curves under dynamic conditions.

The situation is clearer again in Fig. 10, where torque curves for various current levels are presented for cases in which an open loop control system was employed. It is evident that there is a significant difference between the loading and unloading curves for all current levels.
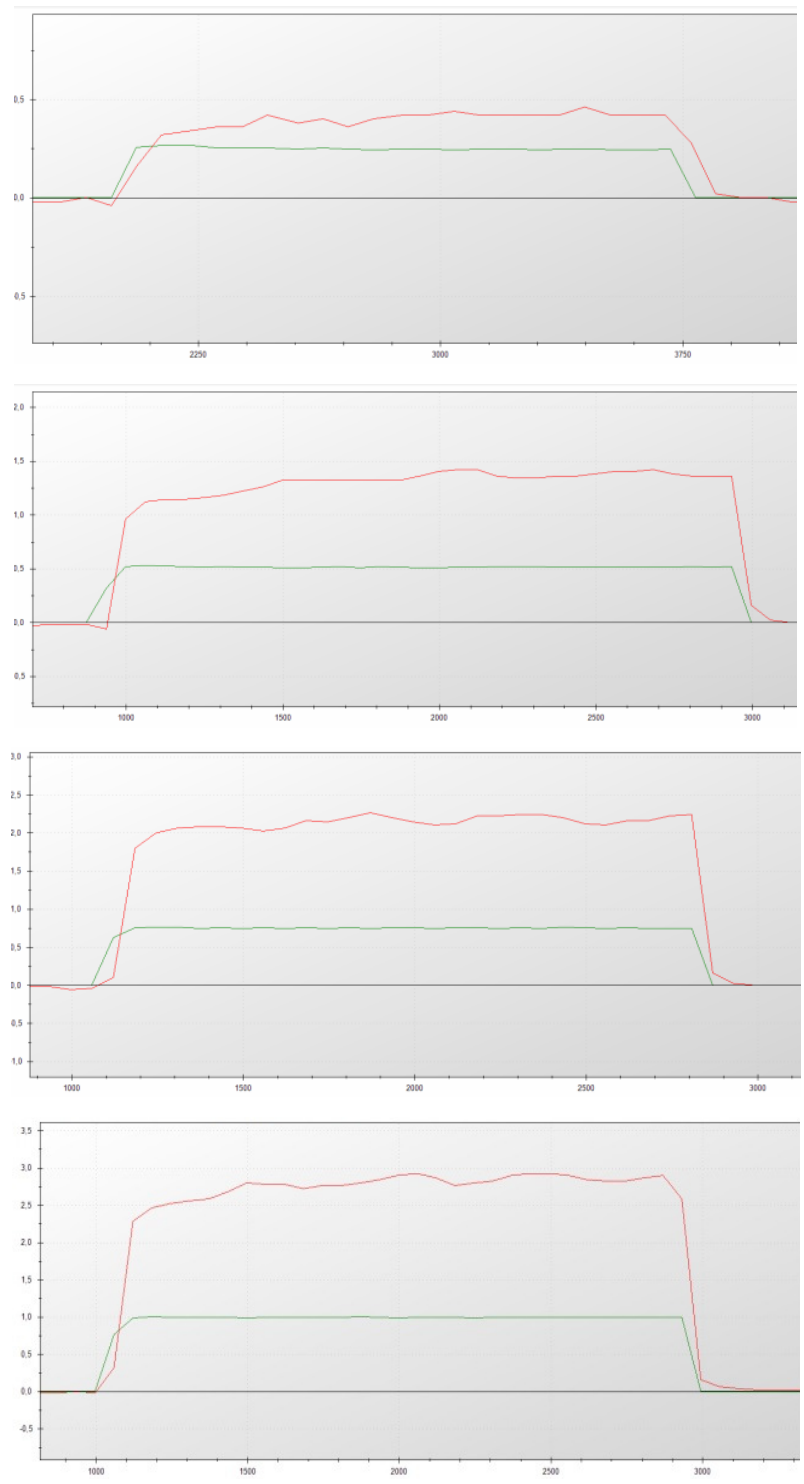

Fig. 10: Torque as a function of time for current levels of $0.25,0.50,0.75$ and $1 \mathrm{~A}$. 
Figure 11 presents the measured current (upper curve) and voltage (lower curve) obtained with the oscilloscope as functions of time (ms). An appreciable delay in the onset of current and therefore torque is evident, with approximately $30 \mathrm{~ms}$ required to reach 50 $\%$ of the final value. The discontinues nature of the curves derives from sample rate limitations in the BRT and signal filters in the RS-232.

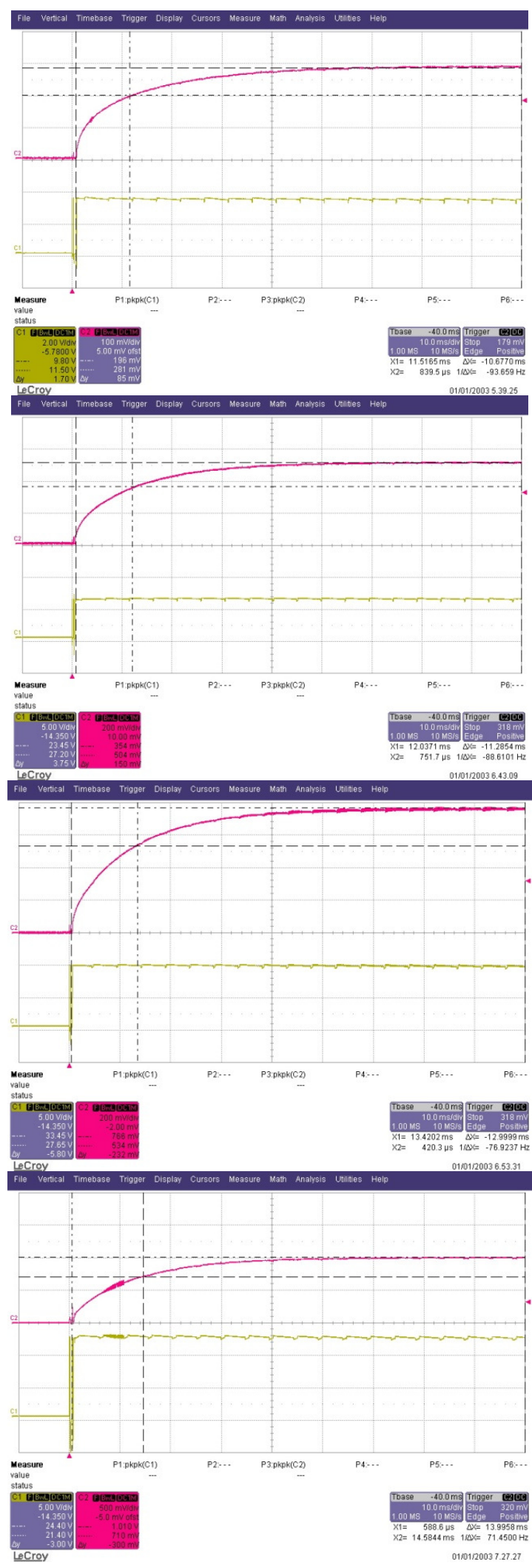

Fig. 11: Transient current for final values of $0.25 \mathrm{~mA}, 0.50$ $\mathrm{mA}, 0.75 \mathrm{~mA}$ and $1 \mathrm{~A}$
System response time allowed signal evaluation with a sample frequency in the range $25-30 \mathrm{~Hz}$, sufficient for dynamic torque control in numerous applications. Amongst the possible sources of delay in the control chain, the time required to induce a magnetic field from the internal windings of the device and produce a change in fluid viscosity was also considered. Nonetheless, despite the relatively large inductance (250 $\mathrm{mH}$ ), this delay was negligible. The step response of the current was obtained by connecting the device winding to a switch and selecting the final required value. The delay with which the final value was achieved was 11$14 \mathrm{~ms}$, equivalent to a sample frequency in the range $70-90 \mathrm{~Hz}$ and therefore considerably faster than that achievable for torque measurement.

\section{CONCLUSION}

The recent growing market interest in magnetorheological fluids derives principally from the ability to employ rapid and simple interfaces between an electrical control signal and a mechanical response. These materials have the potentially to radically change the design of machines in which their implementation is possible. Such a scenario is only possible, however, if devices exploiting these characteristics are capable of guaranteeing actuation via precise and rapid movement. This consideration is even more relevant when their cost is taken into account.

As magneto-rheological devices are electronically controllable, it is possible to use feedback control algorithms to improve their functionality; however, this type of control requires knowledge of device response well beyond that available in the datasheet provided by the manufacturer.

As highlighted in the present work, the torque value obtained at $1 \mathrm{~A}$ applied current under static conditions was only $8 \%$ less than that stated by the manufacturer, $3.4 \mathrm{Nm}$ instead of $3.7 \mathrm{Nm}$, while that obtained under dynamic conditions was some $32 \%$ less than the nominal value of $5.0 \mathrm{Nm}$ [15]. As a result, for applications where the necessary torque is near the nominal value it would be necessary to select a larger model with corresponding increases in cost and weight, or otherwise introduce more complex mechanical systems for increasing torque.

The hysteresis characterization performed under dynamic conditions has also highlighted the necessity to employ a closed-loop current-torque control for all applications where an accurate torque response is necessary under dynamic conditions. It is therefore clear that the commercial magneto-rheological clutch utilized here within has a performance in line with the datasheet from the manufacturer, but with certain limitations associated with a technology that is still very much under development.

\section{ACKNOWLEDGMENTS}

This investigation was supported by the European Union, IPA Adriatic CBC Program within the AdriaHUB project. More details regarding this international collaboration are available in Ref. [19]. 


\section{REFERENCES}

[1] Bingham, E. C.: Fluidity and Plasticity, McGrawHill, New York, 1922.

[2] Tenan, E.: Magnetorheological fluids: a controllable liquid, Il Progettista Industriale, Vol. 03, pp. 86-89: 2006.

[3] Spaggiari, A.: Properties and applications of Magnetorheological fluids, Frattura ed Integrità Strutturale, Vol. 23, pp. 57-61, 2013, doi:10.3221/IGF-ESIS.23.06.

[4] Jolly, M. R., Bender, J. W. and Carlson, J. D.: Properties and Applications of Commercial Magnetorheological Fluids, in: SPIE 5th Annual Symposium on Smart Structures and Materials, San Diego, California USA, 15 March 1998.

[5] Carlson, J. D.: What makes a good MR fluid?, in: Proc. of Lord Corporation, 8th International Conference on Electrorheological (ER) Fluids and Magnetorheological Suspension, Nice, July 9-13, 2001.

[6] Terzo, M.: Developing a semi-active differential using a magnetorheological fluid, $\mathrm{PhD}$ Thesis (in Italian). School of Mechanical Systems, University of Napoli, Napoli, 2007.

[7] Marannano, G. V., Virzì Mariotti, G. and Duboka, C.: Preliminary Design of a Magnetorheological Brake for Automotive Use, in: 23th JUMV International Automotive Conference, Belgrade, Serbia, 19-21 April 2011.

[8] Marannano G., Virzì Mariotti G. and Duboka, C.: Analysis of the Behaviour of an Optimized Magnetorheological Brake, Review of Applied Physics (RAP), Volume 2, No. 2, pp. 23-32, 2013.

[9] Pavlovic, A and Fragassa, C: Numerical modelling the ballistic impacts on flexible curtains used as safety protection in woodworking. in: Proceedings of the Institution of Mechanical Engineers, Part C: Journal of Mechanical Engineering Science, 2016, doi: $10.1177 / 0954406216646401$

[10] Pavlovic, A. and Fragassa, C.: Analysis of flexible barriers used as safety protection in woodworking. International Journal of Quality Research, Vol. 10, No. 1, pp. 71-88, 2016.

[11] Lucisano, G., Stefanovic, M. and Fragassa, C.: Advanced Design Solutions for High-Precision Woodworking Machines, International Journal of Quality Research, Vol. 10, No. 1, pp. 143-158, 2016.

[12] Fragassa, C.: Material selection in machine design: the change of cast iron for improving the highquality in woodworking, in: Proceedings of the Institution of Mechanical Engineers, Part C: Journal of Mechanical Engineering Science. (2016). doi: 10.1177/0954406216639996.

[13] Fragassa, C., Zigulic R. and Pavlovic A: A Practical Guideline for the Design and Use of Tools in Woodworking. Tehnicki Vijesnik - Tehnical Gazette: Vol. 23, No. 3, pp. 557-565, 2016.

[14]Zigulic, R., Fragassa, C. and Skoblar, A..: Influence of the longitudinal displacement on nonlinear principal parametric resonance of the woodworking bandsaw. Tehnicki Vjesnik - Tehnical Gazette: Vol. 23, No. 4, 2016.

[15] http://www.lord.com/products-and-solutions/magneto-rheological-\%28mr\%29/technical-sheets.xml

[16] Yang, L., Duan, F. and Eriksson, A.: Analysis of the optimal design strategy of a magnetorheological smart structure, Smart Materials and Structures, Vol. 17, (2008) 015 047, doi: 10.1088/09641726/17/1/015047.

[17] Marannano, G., Virzì Mariotti, G. and Duboka C.: Analysis of the Behaviour of an Optimized Magnetorheological Brake, Review of Applied Physics, Vol. 2, No. 2, pp. 23-32, 2013.

[18]Zivkovic, I., Pavlovic, A. and Fragassa, C.: Improvements in wood thermoplastic composite materials properties by physical and chemical treatments, International Journal of Quality Research, Vol. 10, No. 1, pp. 205-218, 2016.

[19] Savoia, M., Stefanovic, M. and Fragassa, C.: Merging technical competences and human resources with the aim at contributing to transform the Adriatic area in a stable hub for a sustainable technological development, International Journal of Quality Research, Vol. 10, No. 1, pp. 1-16, 2016.

\section{МАГНЕТНО-РЕОЛОШКИ ФЛУИДНИ УРЕЪАЈИ: НАПРЕДНЕ СОЛУЦИЈЕ ЗА АКТИВНУ КОНТРОЛУ МАШИНА ЗА ОБРАДУ ДРВЕТА}

\section{К. Фрагаса, Л. Берарди, Г. Балсамини}

Детаљна анализа понашања комерцијалних магнетно-реолошких уређаја је представљена у контексту алатних машина за обраду дрвета. Овај тип уређаја може да обезбеди отпорни момент на ротирајућем вратилу путем промене вискозности течности до које долази приликом модификације у магнетном пољу, са отпорним моментом који је пропорционалан струји која пролази кроз електрични намотај унутар уређаја. На овај начин, могуће је контролисати пренос обртног момента променом електричне струје.

Ово решење је посебно релевантно у случајевима где се захтева прецизна контрола обртног момента. Истовремено, познато је да магнетно-реолошки уређаји могу довести до значајног кашњења између активирања контролног сигнала и примене обртног момента. Као последица тога, неопходно је да се анализира понашање квачила директном проценом. Неколико испитивања је извршено повећањем струје и експериментално су процењени примењени момент и хистерезно понашање. Приказани резултати указују на потребу коришћења алгоритамских софтвера којима би се попунила временска разлика између очекиваног и мереног обртног момента и да би се превазишле тешкоће у вези са хистерезисом пре него што се имплементира квачило за прецизне апликације. 